\title{
ALBEDO OF MELTING SEA ICE IN THE SOUTHERN BEAUFORT SEA
}

\author{
By M. P. Langleben
}

(Ice Research Project, Department of Physics, McGill University, Montreal, Canada)

\begin{abstract}
Two Kipp hemispherical radiometers mounted back to back and suspended by an $18 \mathrm{~m}$ cable from a helicopter flying at an altitude of about $90 \mathrm{~m}$ were used to make measurements of incident and reflected short-wave radiation. The helicopter was brought to a hovering position at the instant of measurement to ensure that the radiometers were in the proper attitude and a photograph of the ice cover was taken at the same time. The observations were made in 1969 during 16 flights out of Tuktoyaktuk, Northwest Territories (lat. $69^{\circ} 26^{\prime} \mathrm{N}$., long. $133^{\circ} \mathrm{O}^{\prime} \mathrm{W}$.) over the fast ice extending $80 \mathrm{~km}$ north of Tuktoyaktuk. Values of albedo of the ice cover were found to decrease during the melting period according to the equation $A=0.59-0.32 P$ where $P$ is the degree of puddling of the surface.
\end{abstract}

Résumé. Albedo de la glace de mer fondante dans le Sud de la Mer de Beaufort. Deux radiomètres hemisphériques de Kipp montés dos à dos et suspendus au bout d'un câble de 18 mètres sous un hélicoptère volant à une altitude d'environ 90 mètres ont été employés pour faire des mesures des radiations de courte longueur d'onde incidentes et réfléchies. L'hélicoptère était maintenu en vol stationnaire au moment de la mesure pour être sûr que les radiomètres étaient dans une attitude convenable et une photographie de la couverture de glace était prise au même moment. Les observations furent faites en juin 1969 au cours de vols à partir de Tuktoyaktuk, dans les Territoires Nord-Ouest $\left(69^{\circ} 26^{\prime}\right.$ de latitude Nord, ${ }^{\prime} 33^{\circ}{ }^{\circ} 2^{\prime}$ de longitude Ouest) au dessus de la glace ferme s'étendant à $80 \mathrm{~km}$ au Nord de Tuktoyaktuk. Les valeurs de l'albedo de la surface de la banquise furent trouvées décroissantes au cours de la saison de fusion selon l'équation $A=0,59-0,32 P$ où $P$ est le degré de transformation de la surface par la fusion.

Zusammenfassung. Die Albedo schmelzenden Meereises in der südlichen Beaufort-See. Zwei halbkugelförmige Strahlungsmesser von Kipp-mit ihren Rückseiten gegeneinander montiert und an einem $18 \mathrm{~m}$ langen Kabel unter einem Hubschrauber hängend, der in etwa $90 \mathrm{~m}$ Höhe flog-wurden zur Messung der einfallenden und reflektierten kurzwelligen Strahlung benutzt. Im Augenblick der Messung wurde der Hubschrauber in Schwebeposition gehalten, um sicherzugehen, dass die Strahlungsmesser korrekt ausgerichtet waren; zur gleichen Zeit wurde die Eisoberfläche photographiert. Die Beobachtungen wurden im Juni I969 bei r 6 Flügen von Tuktoyaktuk aus, Northwest Territories (Breite $69^{\circ} 26^{\prime} \mathrm{N}$, Länge $133^{\circ} \mathrm{o2} 2^{\prime} \mathrm{W}$ ), über das $80 \mathrm{~km}$ nördlich von Tuktoyaktuk sich ausdehnende feste Eis angestellt. Die festgestellten Albedowerte der Eisdecke nahmen während der Schmelzperiode entsprechend der Gleichung $A=0.59-0.32 P$ ab, wobei $P$ das Ausmass der Pfützenbildung auf der Oberfläche bedeutet.

\section{INTRODUGTION}

The work described in this paper forms part of a continuing program of measurement of the albedo of sea ice as one of the prime factors influencing the energy budget of the Arctic Basin. Two previous articles (Langleben, I968, I969) presented observations which had been made of the albedo of the ice cover in Tanquary Fiord, Ellesmere Island and which indicated rapid changes in albedo values during the melting season. These papers also reviewed literature on the subject, cited references to earlier work, and stressed the scarcity of available data on the albedo of sea ice and of its variation in time and space.

The observations at Tanquary Fiord clearly indicated that the albedo of the ice cover during the melting season varied linearly with the proportion of the surface covered by puddles of water, its value decreasing as the degree of puddling increased. It was of some interest to test in other parts of the Arctic the applicability of the mathematical relationship which had been established between these variables at Tanquary Fiord. As was pointed out in the previous paper, the ice cover in Tanquary Fiord is subject to surface contamination by dust carried from the adjacent shores by strong winds. It was therefore thought desirable to make airborne measurements of the albedo sufficiently far off-shore to be rid of surface contamination. The observations were made from a helicopter and, for logistic reasons, a small area $(80 \mathrm{~km} \times 100 \mathrm{~km})$ of the Beaufort Sea bordering on Tuktoyaktuk, N.W.T. (lat. $69^{\circ} 26^{\prime}$ N., long. $133^{\circ} \mathrm{O}^{\prime} \mathrm{W}$.) was selected for the aerial survey. 


\section{ObSERVATIONS}

Measurements of total hemispherical incident short-wave radiation and of radiation reflected by the ice cover were obtained using two Kipp radiometers. These instruments had been calibrated before being taken into the field and were recalibrated after use following the procedure outlined in Langleben (1968). The sensitivity of each radiometer, i.e. its calibration constant, remained essentially unchanged under extremely rough treatment.

The radiometers were mounted back to back and fastened to a combined support and electrical cable of $18 \mathrm{~m}$ length by means of a thin trifilar suspension. The other end of the cable was attached to the sling of the helicopter and the electrical connection to a recorder in the cabin was at this point. A ground attendant was required to hold the radiometers off the ground during take-off and to retrieve them on landing.

In flying over the ice, the altitude maintained by the helicopter was typically $90 \mathrm{~m}$ with maximum excursions from this altitude of $\pm \mathrm{I} 5 \mathrm{~m}$. Measurements of incident and reflected radiation were made only when the helicopter was brought to a hovering position to ensure that the radiometers were in a proper attitude with their sensing surfaces horizontal. Photographs of the ice cover were taken simultaneously with the radiation measurements using a very wide angle $\left(94^{\circ}\right)$ lens. From an altitude of $90 \mathrm{~m}$, the field of view of this lens was about $210 \mathrm{~m} \times \mathrm{I} 30 \mathrm{~m}$, large enough to sample a representative area of the ice cover and still to provide sufficient detail of the surface features. Puddles on the ice surface had dimensions from several metres to several tens of metres.

The observations were made during the melting season in June 1969. Sixteen flights were made out of the Polar Continental Shelf Project's base camp at Tuktoyaktuk. The flight paths were over fast ice which extended about $80 \mathrm{~km}$ north from Tuktoyaktuk into the Beaufort Sea. The measurements were started far off-shore where the surface was not contaminated by wind-blown dust. All of the flights, of duration typically $\mathrm{I} \mathrm{h} 45 \mathrm{~min}$, started after I $1.00 \mathrm{~h}$ local time and were completed before I $7.00 \mathrm{~h}$. The solar altitude during the flights lay between $27^{\circ}$ and $43^{\circ}$ and hence the problem of interpreting the response of the Kipp radiometers at low sun elevations did not arise. Furthermore, the helicopter subtended a very small solid angle of about 0.02 steradians at the upward-facing radiometer so that for completely diffuse radiation the influence of the obstruction would be less than $0.3 \%$. Most of the flights however were made during clear periods or when the sky was less than five-tenths overcast.

Surface conditions over the period of observation fortunately varied considerably. Several hundred photographs and simultaneous measurements of radiation were obtained of the ice cover for degrees of puddling varying from several per cent to almost $80 \%$. The period included times when rivulets of melt water flowed over the ice surface and times when surface drainage occurred. Over the clean surface far off-shore, the area surveyed included extensive patches of relatively flat ice and other parts which were covered with networks of pressure ridges.

\section{ANALYSIS AND RESUlts}

The photographic transparencies were projected on to sheets of paper and tracings were made to show the outline of the water puddles. The area of each puddle was measured with a planimeter and the degree of puddling was calculated from the ratio of the area of puddles to the total area shown in the photograph. The corresponding value of albedo for the ice was determined from the ratio of the radiation reflected by the surface to that incident upon it. Some 152 data points were available for analysis and these clearly indicated that the albedo $A$ decreased with increasing degree of puddling $P$. As was shown in Langleben (1969) a linear relationship should exist between the albedo of the ice cover and the degree of puddling. The 
data therefore were fitted by a straight line $A=A_{\mathrm{i}}+\frac{\Delta A}{\Delta P} P$ using the method of least squares and the results are shown in the first row of Table $\mathrm{I}$ as run $\mathrm{I}$.

Table I. Results of Data analysis

$\begin{array}{ccccccc}\text { Run } & \begin{array}{c}\text { Number of } \\ \text { data points }\end{array} & \begin{array}{c}\text { Slope } \\ \Delta A / \Delta P\end{array} & \begin{array}{c}\text { Albedo } \\ \text { intercept } A_{\mathrm{i}}\end{array} & \begin{array}{c}\text { Root-mean-square } \\ \text { deviation in } A\left(\sigma_{\mathrm{A}}\right)\end{array} & \begin{array}{c}\text { Data rejected in } \\ \text { next run if } \delta A>\end{array} & \begin{array}{c}\text { Number } \\ \text { rejected }\end{array} \\ \text { I } & \text { I } 52 & -0.242 & 0.551 & 0.0677 & 0.135 & 15 \\ 2 & 137 & -0.290 & 0.572 & 0.0455 & 0.0910 & 23 \\ 3 & \text { I } 14 & -0.322 & 0.586 & 0.0299 & 0.0598 & 14 \\ 4 & \text { IOO } & -0.325 & 0.586 & 0.0234 & 0.0468 & 19 \\ 5 & \text { 8I } & -0.325 & 0.585 & 0.0174 & & \end{array}$

The intercept $A_{\mathrm{i}}$ corresponds to the albedo of the ice cover before the melt has started and $\delta A$ is the deviation and $\sigma_{\mathrm{A}}$ the root-mean-square deviation of the albedo values from the line of best fit.

It is seen that in run $\mathrm{I}, \delta A$ is quite large having a value of more than $12 \%$ of the albedo intercept. On the scatter diagram of $A$ against $P$ it was apparent that some of the points represented spurious observations and that these accounted in large measure for the excessive root-mean-square deviation in albedo. It is likely that these spurious data were collected on occasions when premature observations were made while the helicopter was still in motion and the radiometers may have been swinging.

The data were examined with a computer program which used an iterative process to reject albedo values whose deviation $\delta A$ from the line of best fit exceeded $2 \sigma_{\mathrm{A}}$. Thus as a result of run $\mathrm{I}$ in Table $\mathrm{I}$, the criterion for rejection in the next run was that $\delta A>2 \times 0.0677$ and 15 data points were rejected on this basis as shown in the last column. Five such runs were made and the results are shown in Table I. It is evident that after the third run, the

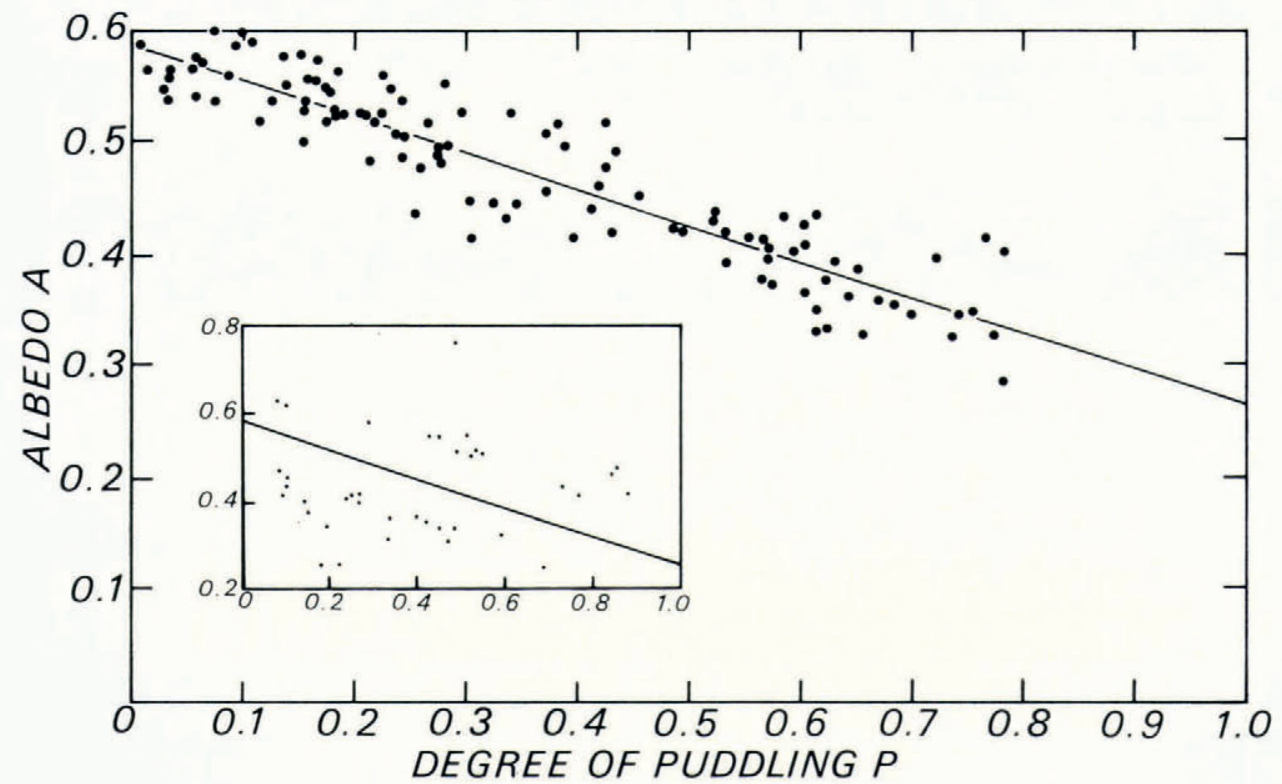

Fig. 1. Albedo of melting sea ice plotted against degree of puddling, southern Beaufort Sea, June 1969. The data rejected as spurious (see text) are shown in the insert. 
change in slope and albedo intercept are negligibly small. Data are being discarded without producing any change in the results obtained. Similar results were obtained, but after more runs, when the criterion for rejection was changed to $\delta A>3 \sigma_{\mathrm{A}}$.

On the basis of run 3 , the data can be represented by the equation

$$
A=0.59-0.3^{2} P \text {. }
$$

These data (I I 4 points) and the line fit are shown in Figure I where albedo $A$ is plotted against degree of puddling $P$. The $3^{8}$ rejected data points are compared with the chosen fit in the insert.

\section{Discussion}

Albedo values during the melt season on fast ice extending about $80 \mathrm{~km}$ north of Tuktoyaktuk were significantly higher (on the average, o.og) than for the ice cover in Tanquary Fiord (Langleben, I969) at similar stages of melting. As in the previous study, the albedo was found to decrease linearly with increasing degree of puddling and its rate of decrease of $0.3^{2}$ agrees with the value of $0.3^{0}$ for Tanquary Fiord. The data for the Beaufort Sea, extrapolated to conditions that prevail before the start of melting and at the other extreme to a fully flooded ice cover, yield values of the albedo of 0.59 and 0.27 respectively. The differences in the albedo of ice in the Beaufort Sea and in Tanquary Fiord were caused by different amounts of surface contamination. In Tanquary Fiord, the distance to the nearest shore from any point was less than three kilometres. The ice therefore was more likely to become sprinkled with wind-blown dust from shore than it was in the Beaufort Sea areas, which were tens of kilometres off-shore.

\section{Acknowledgements}

This study was supported by the National Research Council of Canada under Grant No. A-4232 with logistic support from the Polar Continental Shelf Project, Department of Energy, Mines and Resources. Mr Michael Steven assisted with the field work. The radiometers were calibrated in the laboratories of the Meteorological Branch, Department of Transport.

MS. received 8 April 1970 and in revised form 5 June 1970

\section{REFERENCES}

Langleben, M. P. 1968. Albedo measurements of an Arctic ice cover from high towers. Journal of Glaciology, Vol. 7, No. 50, p. 289-97.

Langleben, M. P. 1969. Albedo and degree of puddling of a melting cover of sea ice. Fournal of Glaciology, Vol. 8, No. 54 , p. 407-12. 